\title{
Teatro fora dos teatros. Arte dramática na prisão, no jardim e no bairro
}

Theater outside theaters. Dramatic art in prisons, parks, and neighborhoods Théâtre hors des théâtres. L'art dramatique dans les prisons, les jardins publics et les quartiers

\section{André Brito Correia}

\section{(2) OpenEdition}

\section{Journals}

\section{Edição electrónica}

URL: http://journals.openedition.org/rccs/1113

DOI: $10.4000 /$ rccs. 1113

ISSN: 2182-7435

\section{Editora}

Centro de Estudos Sociais da Universidade de Coimbra

Edição impressa

Data de publição: 1 Dezembro 2003

Paginação: 55-73

ISSN: 0254-1106

\section{Refêrencia eletrónica}

André Brito Correia, «Teatro fora dos teatros. Arte dramática na prisão, no jardim e no bairro », Revista Crítica de Ciências Sociais [Online], 67 | 2003, colocado online no dia 01 outubro 2012, criado a 02 maio 2019. URL : http://journals.openedition.org/rccs/1113; DOI : 10.4000/rccs.1113 


\section{ANDRÉ DE BRITO CORREIA}

\section{Teatro fora dos teatros. Arte dramática na prisão, no jardim e no bairro}

O teatro dos nossos dias realiza-se muitas vezes em espaços não convencionais, que não foram construídos nem concebidos para acolher eventos desse tipo. Procede-se, então, a uma abordagem sociológica do teatro fora dos teatros, equacionando a relação entre agentes teatrais e espaços não teatrais, de maneira a averiguar o que acontece, em tais casos, à arte dramática. Para tal, analisam-se três criações artísticas que decorreram em Coimbra em 2003: Só entra se vier às fatias (apresentada na prisão); Goblin Market LQL (apresentada no Jardim Botânico) e Quando Estiver Lá em Cima Estará Completamente à Vontade! (apresentada no Bairro da Relvinha). Discute-se o modo como os elementos materiais e físicos do espaço foram mobilizados como partes integrantes ou em interacção com o cenário, texto, luz e som dos espectáculos.

\section{Introdução}

O teatro dos nossos dias realiza-se muitas vezes em espaços não convencionais (praças, igrejas, jardins, museus, prisões, etc.). De acordo com Susan Bennett,

Em anos recentes, tornou-se cada vez mais vulgar edifícios polivalentes (centros comunitários, escolas, sedes de associações, bares, cafés, etc.) servirem como recintos para actuações. Espaços no exterior (parques, lugares históricos, a rua, etc.) tornaram-se igualmente populares. (2003: 127)

A existência de teatro fora dos teatros não nos deve surpreender, pois, como nos diz Richard Schechner,

Se existe uma tradição (e não apenas no Ocidente) de construir grandes edificações especificamente para apresentar actuações - arenas, estádios e teatros - existe igualmente uma longa história de actuações não oficiais “tendo lugar” em locais não imaginados (nem em termos de tamanho nem em termos de uso) arquitectonicamente como teatros. (1998: 198)

No caso do teatro português, nos últimos anos, temos vindo a assistir a múltiplas experiências artísticas realizadas fora das salas de espectáculo convencionais. Num texto dedicado a analisar características do mundo 
teatral no nosso país, Vera Borges assinala a tendência de certos grupos para a utilização de espaços fora dos teatros com o intuito de apresentarem as suas criações artísticas (2002: 97 e 98). Centrada no período que vai de 1996 a 1999, Maria Helena Serôdio, por seu lado, refere o aumento significativo de grupos teatrais nos diversos distritos e afirma que alguns dos projectos desenvolvidos por estes últimos assentaram em "actuações ao ar livre, programas de digressão, experimentação com as tradições populares e o uso estimulante de alguns monumentos históricos para acolher as produções" (1999: 1). ${ }^{1}$ Por seu turno, com o objectivo de analisar a relação entre actividade cultural e espacialidade urbana, Joana Sousa Ribeiro efectuou uma pesquisa empírica comparando o modo como seis agentes culturais ${ }^{2}$ (cinco deles grupos de teatro) intervieram artisticamente "em contextos espaciais não conotados com a 'cultura cultivada'” (2002: 6). Esta autora abordou, assim, diversos casos de teatro apresentado fora dos teatros - em lugares tais como estabelecimentos prisionais, espaços verdes ou mesmo um celeiro agrícola (ibid.: 8).

Apesar de toda a diversidade de experiências teatrais realizadas fora dos teatros, continua a reproduzir-se frequentemente a representação social da arte dramática que associa esta última às peças apresentadas nas salas de espectáculo concebidas para o efeito. Ou seja, o evento teatral aparece como actuação ritualizada que ocorre num espaço com características próprias e diferenciadas.

Augusto Boal, criador do Teatro do Oprimido, conta-nos a seguinte história a partir do trabalho teatral que desenvolveu no Brasil em 2000:

[...] a gente tinha vários grupos, e eu vivo dizendo pra eles que eles são teatro mesmo que não façam teatro, porque ser teatro é você trazer em você o ator, porque você

\footnotetext{
${ }^{1}$ Para ilustrar esta afirmação, Serôdio cita os casos dos grupos Fatias de Cá, Teatro ao Largo, Arte Pública e ACERT (1999: 1). Noutro texto, a mesma autora, ao traçar o perfil artístico das companhias portuguesas de teatro independente, caracteriza $\mathrm{O}$ Bando como estando estruturado em torno de diversos eixos, entre os quais o do "tratamento não convencional do espaço (nas suas actuações realizadas quer no interior quer no exterior), que incorpora esculturas teatrais sugestivas que são ao mesmo tempo funcionais e simbólicas" (Serôdio, 1998: 23). Referindo-se ao facto deste grupo efectuar uma dramaturgia baseada em textos portugueses, Serôdio cita duas criações artísticas em concreto: Bichos (1990) e Gente Singular (1993). A primeira "teve lugar num antigo convento (Beato), usufruindo dos recursos esplêndidos dos seus espaços exteriores e interiores" manifestando-se "no estilo do teatro processional ou de cortejo". Por seu lado, no segundo trabalho artístico atrás mencionado, João Brites, encenador e director deste grupo teatral, "converteu a actuação numa viagem de comboio, usando uma locomotiva a vapor autêntica, com os actores representando quer nas carruagens quer num velho armazém, chamando de volta, portanto, eventos e histórias à volta de 1914" (ibid.).

${ }^{2}$ A saber, Visões Úteis, Teatro Bruto, Teatro Art'Imagem, Teatro da Garagem, A Escola da Noite, Galeria Zé dos Bois.
} 
age, então você é um ator. Mas você é observador das suas ações. O gato, mesmo olhando no espelho, não descobre que aquela imagem é dele. E a gente, mesmo não tendo espelho, sabe como é que está. A gente está se vendo mesmo não tendo espelho, não é isso? Então eu falava "Vocês são teatro, mesmo que não façam. Mas vocês também fazem teatro". Aí, um dia, eles chegaram pra mim e disseram: "Escuta, você vive falando pra gente que a gente faz teatro, que a gente é teatro, mas a gente só representa na rua, no Aterro do Flamengo, e nunca dentro de um teatro. Então vamos fazer dentro de um teatro". Eu não queria porque achava que não era necessário. Mas eles insistiam tanto, então vamos fazer. (apud Amaral et al., 2001: 33)

O caso acabado de citar ilustra bem o facto de se pensar muitas vezes no teatro enquanto forma artística que decorre nos teatros. Este fenómeno prende-se certamente com a lógica de diferenciação do espaço público promovida pela modernidade. A designação de um edifício (ou de uma zona) como sendo um teatro "actua para sinalizar o evento levado à cena no seu interior como actuação teatral” (Bennett, 2003: 127). No que diz respeito às actividades culturais, a realidade diferenciada do espaço articulou-se com a presença e influência da burguesia. Como nos diz Paolo Portoghesi, "a sociedade burguesa em ascensão foi capaz de providenciar uma forma estável para as suas próprias necessidades através da criação de edifícios como o teatro, a galeria pública, o museu e a biblioteca" (apud Bennett, 2003: 129). Não admira, portanto, que a dimensão arquitectónica dos espaços designados como teatrais seja interpretada como símbolo da alta cultura (Bennett, 2003: 129). ${ }^{3}$ Acrescente-se ainda que, "a última fase de construção de teatros, quer na Europa quer na América do Norte, foi largamente modernista em termos de design e intenção, e como tal codificada ideologicamente para aprovar e acolher a sociedade burguesa que financiava as instituições" (ibid.).

Deste modo, a abordagem das intervenções artísticas em espaços que não foram concebidos para as receber permite questionar a lógica de diferenciação do espaço público e das dicotomias de ordenamento sócio-espacial e cultural características da modernidade: público/privado, puro/impuro, consagrado/não consagrado, culturalmente dominante/culturalmente dominado (Ribeiro, 2002: 1, 4 e 12).

Uma reflexão sociológica sobre o teatro fora dos teatros que equacione a relação entre agentes teatrais e espaços não teatrais pode desenvolver-se, de facto, tentando averiguar o que acontece a esses espaços quando o teatro aí se concretiza. Contudo, pode igualmente centrar-se na questão de saber o

\footnotetext{
${ }^{3}$ Susan Bennett diz-nos ainda que "alguns teatros que nasceram como centros de entretenimento popular foram recuperados através do tempo pela alta cultura em virtude da sua importância histórica" (2003: 129).
} 
que acontece, em tais casos, ao teatro. É esta segunda perspectiva que se adoptará neste texto. Neste sentido, serão analisadas três criações teatrais em particular, tendo em conta o modo como os elementos materiais e físicos do espaço são mobilizados como partes integrantes ou em interacção com a cenografia, texto, luz, som e/ou música dos espectáculos em causa. Só uma tal mobilização permite afirmar que se trata a espacialidade sem a reduzir a um mero receptáculo. Ou seja, um teatro fora dos teatros não é equivalente ao teatro que se faria nos teatros retirando-lhes simplesmente as paredes.

Se é importante perceber de que modo os agentes sociais e grupos recriam e se apropriam do espaço urbano, é lógico que nos interroguemos sobre o modo como os grupos de teatro o fazem. Não pretendo, contudo, dar conta da diversidade de opções estéticas subjacentes às representações teatrais que decorrem fora das salas de espectáculo ${ }^{4}$ nem tão pouco enumerar e caracterizar a multiplicidade dos locais escolhidos como espaços cénicos.

Os casos de teatro fora dos teatros que serão objecto de atenção nos três pontos seguintes deste texto revelam-se como intervenções artísticas que dinamizaram espaços públicos urbanos, orientando-os, de alguma forma, para uma lógica desdiferenciadora. Com efeito, tais criações teatrais ocorreram em locais que não foram concebidos para a apresentação de espectáculos de teatro: um estabelecimento prisional, um jardim, um bairro. Estamos perante contextos espaciais muito diversos entre si, quer em termos de dinâmicas sociais quer em termos de configuração material e arquitectónica, facto que proporciona condições muito variadas para o diálogo com elementos da arte dramática como sejam a cenografia e o texto. A prisão aparece como um espaço de reclusão e de acesso limitado, que o teatro abre para um público mais vasto; o jardim, espaço de fruição com a natureza, surge como lugar ocupado abertamente pela cultura, ${ }^{5}$ o bairro, uma zona da periferia da cidade sem nenhum edifício teatral, constituiu-se como um vasto espaço cénico atraindo espectadores do centro da cidade ou frequentadores dos equipamentos culturais existentes nesta última.

$\mathrm{Na}$ pesquisa atrás referida de Joana Sousa Ribeiro, esta autora constatou que "a apropriação para fins culturais de espaços como os estabelecimentos

\footnotetext{
${ }^{4}$ Como é óbvio, a arte teatral que ocorre em espaços não concebidos funcionalmente para o efeito não se constitui como um género dramático único. Com efeito, os espectáculos apresentados fora dos teatros podem filiar-se nas mais diversas correntes estéticas e artísticas: podemos assistir a manifestações teatrais mais próximas da animação e do entretenimento ou mais próximas do teatro antropológico ou ainda de um teatro mais empenhado politicamente, para fornecer só alguns exemplos.

${ }^{5}$ É óbvio que a experiência humana da natureza é sempre mediada culturalmente, mas, no caso em apreço, essa culturalização torna-se presença consciente e constantemente visível da fruição do ambiente "natural".
} 
prisionais, os Jardins do Palácio de Cristal [...], ou ainda, edifícios cuja função industrial foi desactivada, constitui uma oportunidade para reintroduzir esses lugares no tecido urbano" (2002: 8). Penso que o mesmo se pode dizer relativamente às três criações teatrais que a seguir analiso - duas delas referentes igualmente a locais com função de reclusão e de espaços verdes.

Para concluir este texto, apresentarei algumas pistas para investigações futuras que possam desenvolver a abordagem sociológica do teatro fora dos teatros enquanto processo reflexivo e criativo.

\section{Teatro na prisão: Só entra se vier às fatias}

Uma das maneiras pelas quais se pode detectar a desdiferenciação do espaço escolhido para apresentação de um espectáculo é verificando se este último suscita surpresa e estranheza na medida em que acolhe artistas e grupos teatrais.

A este respeito, o teatro realizado nas prisões parece-me ser um caso exemplar e, por isso, merecedor de um comentário mais alargado. Paul Heritage, director do People's Palace Projects (organização da Universidade de Londres) e organizador de programas teatrais em prisões recorrendo à metodologia do Teatro do Oprimido, refere o seguinte: "Fazer teatro em prisões é um meio de encenar encontros impossíveis. Todas as grandes peças teatrais parecem originar-se de um encontro que não deve ou não pode acontecer: Édipo com seu pai; Romeu com Julieta; Estragon e Vladimir com Godot" (2001: 32). ${ }^{6}$

Isto não significa obviamente ignorar as grandes dificuldades com que tais projectos teatrais se defrontam. Paul Heritage refere claramente e com muita agudeza tais obstáculos, como, por exemplo, aqueles respeitantes ao acesso à prisão, a conseguir um espaço aí dentro para trabalhar ou "como persuadir os presidiários de que o teatro não os exporia ao risco do ridículo (ou coisa pior) pelos guardas ou pelos outros internos" (ibid.).

\footnotetext{
${ }^{6}$ O Teatro do Oprimido consiste numa série de técnicas e exercícios através dos quais se pretende que o espectador abandone a sua posição de mero observador da acção dramática para se tornar interveniente activo nesta última; daí o conceito de Espect-Actor (Boal, 2000: xxi). O Centro de Teatro do Oprimido do Rio de Janeiro (CTO-Rio), criado em 1986 e dirigido por Augusto Boal, desenvolve uma série de actividades de formação, criação e difusão teatrais que se estruturam à volta de três projectos principais. Um deles intitula-se Direitos Humanos em Cena e reconduz-nos à ideia de levar o teatro às prisões. Com efeito, pretende-se envolver presos e agentes prisionais na montagem e concretização de sessões de teatro-fórum, onde, depois de apresentadas cenas de opressão, os espectadores podem substituir o personagem oprimido e ensaiar formas concretas de modo a eliminar o efeito de dominação e exclusão de que este foi vítima. Este projecto resulta da colaboração entre o CTO-Rio, o People's Palace Projects e a FUNAP (fundação que tem a seu cargo o sistema educativo dos estabelecimentos prisionais do Estado de São Paulo).
} 
Antes de analisar com algum detalhe um espectáculo teatral efectuado num estabelecimento prisional, gostaria de citar o caso do Visões Úteis, grupo de teatro profissional portuense, que iniciou, em 1997, o Projecto Liberdades com o intuito de fazer chegar o teatro às prisões. Para isso, resolveu efectuar uma adaptação de um trabalho apresentado em 1995, Subterrâneo de Dostoievski. A escolha foi ditada pela facilidade da montagem desta peça em estabelecimentos prisionais e pela temática que abordava. Deste modo, foi possível apresentar este espectáculo em 16 prisões durante dois anos. Posteriormente, o Visões Úteis produziu O Veredicto, com texto de Franz Kafka. Esta criação colectiva do grupo portuense foi apresentada em 33 estabelecimentos prisionais. No dizer da companhia, tratou-se de "um espectáculo pensado de raiz para este tipo de espaços, para aí ser estreado e só depois apresentado ao público que está «cá fora»." (Visões Úteis, 1999: 22). O Projecto Liberdades marcou, assim, significativamente o percurso deste jovem grupo teatral português e foi concebido dentro de um espírito de proporcionar a fruição teatral a um público que dela se encontra afastado, pretendendo-se com isso suscitar as mais variadas sensações e experiências:

[...] Não fazemos este projecto com espírito de missão ou porque nos julgamos melhores que os outros, mas sim porque gostamos de levar teatro onde não o há, quer seja numa prisão quer seja em aldeias perdidas no interior ou em bairros degradados de uma cidade. Em qualquer um destes locais a informação de um mundo em permanente evolução não chega por falta de meios, ou por preconceito, ou simplesmente por "dar trabalho". As pessoas ficam menos aptas à sobrevivência, menos dotadas de meios, menos versáteis e a exclusão social acontece.

Achamos que o teatro nas prisões pode ter várias funções: ajudar a meditar, despertar, divertir ou somente para ajudar a passar o tempo e quebrar a monotonia. (ibid.)

Para dar conta quer da acção teatral na extrema não convencionalidade do espaço da prisão quer do diálogo existente entre ambos, recorrerei à análise do espectáculo Só entra se vier às fatias, encenado por Andrzej Kowalski, com dramaturgia de Luís Mourão e apresentado no Estabelecimento Prisional de Coimbra de 17 a 20 de Dezembro de 2003 com início marcado para as $21 \mathrm{~h} 30 \mathrm{~m}$. Esta produção artística inseriu-se na programação da Coimbra 2003, Capital Nacional da Cultura. ${ }^{7}$

\footnotetext{
7 Resultou de um protocolo de cooperação assinado entre esta última e o referido estabelecimento prisional a 18 de Julho de 2003 (Coimbra 2003, 2003a). Durante o encontro realizado para o efeito, Eugénio Coelho, director do Estabelecimento Prisional de Coimbra, chamou a atenção para a existência, no interior da entidade que supervisionava, de vários grupos de presos que se dedicavam a actividades artísticas (ibid.).
} 
A articulação entre criação teatral e o espaço onde esta se apresentou está patente, desde logo, no seu título. ${ }^{8}$ Com efeito, este último, nas palavras de Kowalski, "tem tanto a ver com a sensação geral de quem entra na prisão como com um pequeno cartaz que acolhe os visitantes à entrada do parlatório: «tudo o que possa camuflar um objecto de agressão ou facilitador de fuga só entra se vier às fatias»" (apud Coimbra 2003, 2003b). A expressão que deu nome ao espectáculo em causa foi, aliás, utilizada por diversas vezes nas falas dos personagens, dando conta da fragmentação e experiência cortante gerada pela prisão naqueles que aí estão cativos.

A singularidade desta criação teatral prende-se em boa medida com o facto dos actores, mais de uma dezena, serem todos presos do Estabelecimento Prisional de Coimbra, "quase todos estreantes" (Coimbra 2003, 2003c). Além disso, os textos usados foram fundamentalmente da autoria desses mesmos reclusos. Os ensaios decorreram com base num trabalho de improvisações e de conversas com os actores.

O espectáculo criado centrou-se nas experiências daqueles que estão enclausurados na prisão. Deu-nos conta do quotidiano prisional sem se reduzir, no entanto, a um teatro-documento mero retrato da realidade. Com efeito, o lado poético/simbólico e ficcional assumiu um papel importantíssimo. O evento artístico em causa não se deve classificar como um exemplo de realismo teatral. Nas palavras do seu autor e encenador, "não é um espectáculo realista, nem de perto nem de longe: é um bocado surrealista" (Kowalski apud Morais, 2003: 24).

Numa primeira parte da peça, cada um dos personagens dava conta da chegada à prisão e de como isso afectou poderosamente a identidade pessoal: despojamento de bens e roupas próprias, atribuição de um número a partir do qual passariam a ser identificados, número de anos em que consistia a pena atribuída. Estes momentos do espectáculo serviam como uma espécie de apresentação da maneira como cada preso se via privado de referências subjectivas, ou seja, remetiam para o tipo de processos que, por exemplo, Erving Goffman (1975) salientou ao abordar a acção das instituições totais. Posteriormente, assistíamos a cenas de diálogo e interacção entre os personagens, através das quais se ia dando conta do constrangimento e coerção do contexto prisional bem como da forma como se podia lidar com isso.

Até esta parte da peça, a actuação podia ser lida de uma maneira muito colada às circunstâncias reais do dia-a-dia prisional. No entanto, a dimensão poética e simbólica ganhou novo fôlego, a partir do momento em que

\footnotetext{
${ }^{8} \mathrm{Na}$ análise dos elementos anteriores à actuação artística que contribuem para activar o enquadramento teatral, Susan Bennett (2003: 138) inclui o título das peças, ao mesmo tempo que assinala a sua importância.
} 
os personagens decidiram empreender a tarefa de construir colectivamente um barco, para escaparem da prisão. Os espectadores eram, assim, convidados a acompanhar as vicissitudes de tal empreitada. Ao barco seria dado o nome de Grito e a sua entrada em cena constituiu um dos momentos mais marcantes da actuação teatral. Associado ao desejo de liberdade (com efeito, que território mais amplo e contrastante com a finitude e emparedamento das prisões se poderia arranjar senão o mar, o oceano?), este objecto ver-se-ia, contudo, impossibilitado de proporcionar a evasão aos reclusos. Sobre este assunto, voltarei a falar mais adiante.

Em Só entra se vier às fatias, a teatralidade tece ligações muito fortes com o espaço onde se apresenta havendo um envolvimento muito intenso do segundo na primeira. O Estabelecimento Prisional de Coimbra situa-se no centro da cidade junto aos Arcos do Jardim, na Alta, próximo do Pólo I da Universidade. Depois de entrarem por um dos portões para a prisão, os espectadores ficavam à espera numa espécie de "foyer" ao ar livre, onde estava igualmente uma mesa para o serviço de bilheteira. ${ }^{9}$ Os espaços de espera dos teatros actuam habitualmente como dispositivos sociais onde os indivíduos observam e se sentem observados num ambiente de lazer que pode incluir diversos serviços que atestam a identificação e gosto culturais (Bennett, 2003: 130 e 131). No caso em análise, o foyer, dado o seu carácter improvisado, não estava estruturado como dispositivo social da mesma forma em que se encontram aqueles existentes num equipamento teatral (ninguém imaginava, certamente, que poderia ir ao bar ou ver alguma montra com livros de teatro ou CD's). No entanto, funcionou como uma verdadeira antecâmara para o espectáculo em causa. Com efeito, enquanto os espectadores estavam à espera que a peça começasse, podiam dar-se conta de parte das instalações da prisão e do modo como o portão por onde entraram era controlado por um sistema de segurança e de abertura muito próprios. Ao mesmo tempo, havia uma pessoa encarregada de fazer uma breve inspecção a cada espectador para ver se trazia algum objecto interdito.

Mais tarde, o público tinha de subir um pouco até à entrada de um túnel onde decorreria o espectáculo. Nos primeiros momentos, os espectadores aí se concentraram e depararam-se com "aquela relíquia sinistra de uma carruagem celular, exemplar único no país, que o EPC [Estabelecimento Prisional de Coimbra] quer restaurar com o apoio do Museu dos Coches" (Vieira, 2003: 37). Mais à frente, encontravam-se os actores, uns a seguir aos outros, perto de cada uma das paredes do túnel. A actuação começou podendo ouvir-se os primeiros passos do texto. O público foi avançando

\footnotetext{
${ }^{9}$ Note-se que, para se obter os bilhetes para este espectáculo, era necessário que os espectadores apresentassem dados do seu B.I.
} 
pelo túnel adentro e observava os actores que permaneciam em pé ao longo deste último. Posteriormente, os intérpretes reuniram-se e avançaram para a zona onde decorreria a maior parte da acção - para lá chegar, era preciso passar por um portão gradeado, ao qual se seguiam uma série de bancos (para os espectadores), estando à sua frente um espaço ladeado "por prateleiras de madeira cheias de formas de sapatos cobertas de pó, provenientes de antigas oficinas de sapataria" (ibid.). Mais ao fundo, estava um pano branco que impedia que se visse o que quer que fosse para além dele. Foi nesta zona do túnel tendo prateleiras à sua direita e à sua esquerda que os actores desenvolveram a sua actuação. Na descrição do jornalista Álvaro Vieira, "a luz é amarela e baça, as paredes têm rachas e estão raiadas de uma humidade verde que acentua o cheiro a cadafalso" ( $\mathrm{ibid}$.).

O espaço usado não podia dialogar melhor com a acção teatral. De facto, actores e espectadores estavam situados dentro de um túnel fechado, sem nenhuma porta, janela ou comunicação com o exterior visíveis. Deste modo, a realidade de fechamento e claustrofobia da prisão, objecto de tratamento dramatúrgico na peça, era intensificada e feita sentir aos que estavam presentes. O próprio portão gradeado situado no meio do túnel reforçava este efeito. De facto, sublinhou a imagem de grades na qual se pode materializar o conceito de privação de liberdade. Além disso, reforçou a sensação da porta como mecanismo de fechamento e não de abertura, como acontece na experiência dos reclusos, aliás. O portão em causa só pode ser entendido como um reforço da segurança que tenta impedir a fuga ou circulação proibidas - se um túnel é um lugar de passagem, porquê barrá-lo com portões internos? Só tem sentido, se se estiver num meio com função de clausura, como é óbvio. Interessante é o facto de inicialmente a Coimbra 2003 e o estabelecimento prisional em causa terem pensado em "organizar um espectáculo que os reclusos apresentariam no exterior. Mas o encenador apaixonou-se pelo espaço [do túnel]" (Vieira, 2003: 37). Além disso, o facto dos actores serem reclusos e de se estar no meio de uma verdadeira prisão - a mesma onde estes cumpriam penas - gerava um efeito dramático próprio quando os personagens se apresentavam e dialogavam entre si sobre a realidade incontornável do seu encarceramento.

O barco construído pelos personagens para conseguirem fugir da prisão é talvez o elemento mais marcante, do ponto de vista simbólico, da actuação teatral em causa. Escondido durante larga parte do tempo atrás do pano branco anteriormente mencionado, quando era posto a descoberto, provocava surpresa e algum deslumbramento no espectador. Quem podia sonhar encontrar assim um objecto no meio de uma prisão - meio bicicleta, meio caravela, meio barcarola? Aliás, a própria ideia da impossibilidade de 
descobrir um barco numa prisão simboliza bem a ideia da encenação de encontros impossíveis em que consiste o fazer teatro nas prisões de que falava Heritage.

O barco de Só entra se vier às fatias está no centro das preocupações dramáticas geradoras deste espectáculo. Como nos diz o jornalista Nelson Morais,

A partir do momento em que foi dada aos presidiários da Penitenciária de Coimbra a possibilidade de serem eles próprios a construir o texto, o tema da fuga tornou-se incontornável. Mas, para não fugir à realidade, do que verdadeiramente se fala no espectáculo é da "possibilidade de fuga”, precisa Kowalski. Daí a ideia do barco, símbolo do desejo da liberdade que não se concretiza, mas que teimosamente permanece no pensamento de quem está preso. "O barco é o sonho da saída”, contava [...] um dos actores, num encontro com a comunicação social. (2003: 24)

O lado radicalmente simbólico e atractivo do barco construído reside igualmente no facto de poder sinalizar o movimento contrário do cortar às fatias, gesto de fragmentação, separação, divisão. Com efeito, o barco dos personagens só ganhou existência pela união dos seus esforços, pela junção de peças e elementos materiais que se articularam para fazerem parte daquele objecto. Cada personagem deixou de actuar como se fosse um fragmento isolado.

É verdade que, na acção teatral criada, o barco acabaria por não permitir aos personagens a fuga da prisão, mas trata-se, afinal, de uma boa metáfora da própria peça que lhe deu vida - permitiu aos reclusos sonhar, criar, transcender de algum modo o quotidiano rotineiro que levam na clausura da prisão; permitiu juntá-los no esforço colectivo de fazer algo - os personagens fizeram o barco, os actores fizeram teatro. Só entra se vier às fatias foi provavelmente para os intérpretes o seu verdadeiro Grito.

Para terminar este ponto do texto, gostaria apenas de acrescentar que, dado o especial envolvimento espacial verificado na actuação artística analisada, estamos perante um espectáculo teatral, de certo modo, especificamente situado. Isto significa que a sua transposição para um equipamento cultural convencional ou para outro contexto que não o de uma prisão implicaria inevitáveis perdas do ponto de vista da sua intensidade dramática e projecção no público.

\section{Teatro no jardim: Goblin Market $L \& L$}

A utilização de um espaço não convencional para a actuação teatral permite ampliar a nossa perspectiva e converter objectos, dispositivos, equipa- 
mentos, ambientes e referências geográficas em elementos de ficção, imaginação e surpresa. O uso e apropriação criativas e dinâmicas de lugares como mosteiros, igrejas, ruas, parques e bairros permite transportá-los para uma dimensão de sonho, fantasia ou transfiguração onde as suas qualidades como objectos físicos se tornam materiais para a esfera de fruição estética proposta.

Neste sentido, gostaria de referir o exemplo concreto da criação artística intitulada Goblin Market LEL, produzida pelo grupo de Coimbra arexploratóriodasartes ${ }^{10}$, e concebida a partir do poema Goblin Market de Christina Rossetti, poeta inglesa do século XIX. O ar identifica-se como "um exploratório interdisciplinar de pesquisa" (ar, 2003) e refere que, nas suas actividades, se salientam, entre outras características, "a pesquisa e experimentação de espaços alternativos para as artes performativas contemporâneas” (ibid.).

Goblin Market LEL foi apresentado em Julho de 2003 e foi co-produzido pela Coimbra Capital Nacional da Cultura. A actuação teve lugar na Mata do Jardim Botânico da Universidade de Coimbra ${ }^{11}$ e tinha sempre início marcado para as 17 horas. A sua natureza especificamente situada adveio da extrema cumplicidade que estabelecia com o ambiente onde se desenrolava. O Jardim Botânico foi criado em 1772 e faz parte da Universidade de Coimbra. Actualmente apresenta uma área de 13,5ha (Jardim Botânico de Coimbra, s/d-b: 2), distribuída por duas zonas principais: "uma mais elevada, talhada em socalcos e ajardinada que se localiza no topo de uma pequena colina; a outra, estendendo-se em declive até ao sopé desta elevação, constitui o que vulgarmente se denomina como «Mata»" (ibid.). Nesta segunda zona, podemos encontrar "uma vegetação densa cuja parte arbórea é predominantemente exótica” (ibid.).

A Mata do Jardim Botânico converteu-se num espaço cénico com inegáveis qualidades para participar na acção dramática concebida a partir do universo poético de Christina Rossetti. O poema Goblin Market pode ser interpretado como um texto que, sob a aparência de conto infantil, dá conta

\footnotetext{
${ }^{10}$ Esta estrutura profissional surgiu em 2001 e é dirigida artisticamente por Lúcia Ramos. As suas anteriores produções foram igualmente apresentadas em espaços fora dos teatros ou num espaço menos habitual dentro do teatro: ARDE TEMPO (Ala vaga do Laboratório Chimico - Universidade de Coimbra - e Pátio Interior do Museu Nacional Machado de Castro, Coimbra); NÃO QUERO MAIS CONVERSA (café-teatro do Teatro Académico de Gil Vicente, Coimbra); $A[R] M A$ \& $M E$ (Antigo Refeitório do Mosteiro Santa Cruz, Sala da Cidade, Coimbra) e ARIEL (Colégio das Artes, Museu Nacional da Ciência e da Técnica, Coimbra).

${ }^{11}$ Registe-se que, na página electrónica deste Jardim Botânico, existe um texto intitulado "Mensagem" (Jardim Botânico da Universidade de Coimbra, s/d-a) onde se apresenta o convite para quem quer que seja conhecer ou colaborar com esta entidade na concretização de projectos tais como os de carácter lúdico e de animação cultural.
} 
das questões do desejo feminino, da sensualidade, da tensão entre racionalidade/dever social e emotividade/subjectividade individual. A dimensão onírica do texto foi reconstruída através do ambiente singular da Mata do Jardim Botânico: aí desapareciam ou reapareciam os goblins que, pelos seus caminhos e arvoredo, se ocultavam, se davam a ver um pouco ou se revelavam por inteiro. Estes seres tentavam seduzir as irmãs Lisa e Laura a comprar frutas do pomar, ou seja, os objectos simbólicos de desejo e prazer. A visão e audição dos espectadores não ficavam circunscritas a um lugar finito ou limitado a quatro paredes. As fronteiras do espaço pareciam perder-se na imensa e densa vegetação à sua volta, criando-se assim uma atmosfera atemporal, maravilhosa e misteriosa.

Se, muitas vezes, quem assistia à actuação era convidado a concentrar-se atentamente em sítios mais diminutos e particulares (por exemplo, na zona onde moravam ou se recolhiam as irmãs), em muitas outras alturas pairava a dúvida sobre qual o ponto adequado para onde se devia olhar ou para onde se podia desviar a atenção. Os espectadores viam-se muitas vezes obrigados a procurar vislumbrar goblins por perto, a perguntar onde estariam a cantar e a mexer na vegetação, a interrogar-se por onde irromperiam e quais os avanços que se permitiriam fazer rumo ao espaço mais circunscrito onde viviam Lisa e Laura, ou seja, rumo à "Capela de S. Bento" do Jardim Botânico. Esta construção, "datando do séc. XVII, apresenta-se de forma quadrada, coberta por uma cúpula, e separada das terras envolventes por uma escada" (Jardim Botânico de Coimbra, s/d-b: 2) e terá servido como oratório na época dos frades beneditinos.

Era precisamente nas proximidades desta capela que os espectadores permaneciam sentados enquanto observavam o desenrolar da acção dramática. Deste modo, podiam igualmente deparar-se com um bambual nas suas imediações.

$\mathrm{Na}$ actuação teatral, a sedução era activada, muitas vezes, pelos cantos colectivos dos goblins, sons e melodias que, ao dialogarem com o espaço, se tornavam misteriosos e objecto de curiosidade, geradores de tensão e expectativa e símbolos de energia e de tentação forte e persistente. Tudo dependia do modo como a sonoridade contracenava com o espaço da Mata: por vezes, não era possível saber ao certo de onde partiam os cantos e onde estava quem os cantava; outras vezes, música e palavra iam-se aproximando mas sem se saber muito bem ainda onde estava a sua fonte; noutras ocasiões, os goblins assomavam-se ou iam aparecendo com a sua canção e, noutras alturas ainda, estes seres misteriosos avançavam visivelmente em passos e corridas enérgicas e solicitadoras cantando ao mesmo tempo. Quando uma das irmãs cantava, os sons conjugavam-se com a atmosfera de sonho e poeti- 
cidade desprendidos do texto. A Mata parecia um lugar ideal para acolher os estados de espírito revelados, a sensibilidade manifesta e o tom encantatório envolvente. Os prédios, edifícios, ruas e praças da cidade de Coimbra pareciam estar muito longe e o espectador podia sentir-se como se estivesse num bosque perdido algures, sem referências claras de tempo e de geografia.

O desenho de luz originava-se fundamentalmente nos efeitos solares que atravessavam o Jardim Botânico. A Mata funcionou como uma filtragem natural que deixava passar mais ou menos luz solar; o sol, por vezes, ficava mais encoberto ou pálido e, assim, sem que nenhuma acção humana interferisse, apareciam momentos mais iluminados ou ensombrados.

Sobre este espaço cénico ampliado e de proporções alternativas, o ar escreveu o seguinte:

A Mata do Jardim Botânico, lugar privilegiado de aproximação e contacto com a vida no seu estado mais selvagem, serviu-nos de palco. Ali vivemos um tempo de reencontro com o vento, os rumores da folhagem, os bichos e a terra. E ali ficarão, agora, a habitar as nossas personagens (2003).

\section{Teatro no bairro: Quando Estiver Lá em Cima Estará Completamente à Vontade!}

Nos casos em que uma determinada actuação teatral realizada num espaço não convencional se envolve de tal maneira com esse ambiente físico que se torna impossível apresentá-la noutro sítio qualquer, mesmo numa versão modificada, estamos perante um caso radical do projecto especificamente situado. Isto significa que entre o espaço utilizado para a apresentação de uma peça e a concretização desta última se desenvolve uma extrema cumplicidade. Aqui estamos perante o caso oposto ao da actuação que utiliza um lugar fora dos teatros apenas como mero receptáculo disponível para se fazer algo que se apresentaria quase da mesma forma ou até de uma forma mais eficaz ou ideal numa sala de espectáculos.

Um exemplo de criação radicalmente localizada num contexto não convencional de representação e fruição teatrais é o do espectáculo Quando Estiver Lá em Cima Estará Completamente à Vontade!, organizado pela Pro Urbe - Associação Cívica de Coimbra - e inserido também no programa da Coimbra Capital Nacional da Cultura. Esteve programado para os dias 5, 6 e 7 de Setembro de 2003 com início às $21 \mathrm{~h} 30 \mathrm{~m}$. Resultou do trabalho efectuado no Laboratório de Encenação e Dramaturgia dirigido por Carlos J. Pessoa e no Laboratório de Espaço Cénico e Arquitectura dirigido por João Mendes Ribeiro. Nestes laboratórios, realizados em Agosto no próprio 
bairro onde se realizaria o evento artístico, participaram pessoas, "que dão corpo e forma ao espectáculo - são eles os actores e os autores dos espaços cénicos” (Loureiro, 2003: 16). Carlos J. Pessoa dá-nos mais informações: "as pessoas que estão a trabalhar nos laboratórios não são profissionais, na maioria são estudantes, de teatro, de arquitectura e de outras áreas, há uma diversidade disciplinar cativante, mas têm tido um empenho e disponibilidade inexcedíveis" (apud Loureiro, 2003: 16).

O espectáculo Quando Estiver Lá em Cima Estará Completamente à Vontade! inseriu-se naquilo que foi chamado de projecto relvinha.cbr_x, que envolveu cerca de 40 indivíduos. Este projecto foi criado e coordenado por Luís Sousa, Tiago Hespanha e Vasco Pinto. Realizou-se, assim, um processo artístico articulado com a reflexão e intervenção num espaço específico da cidade de Coimbra. O espaço em causa foi o Bairro da Relvinha, zona periférica do Norte desta localidade. Para isso contou-se com a activa participação da Cooperativa de Construção e Habitação Económica Semearrelvinhas, CRL. Procedeu-se, assim, a um trabalho de diálogo com os moradores deste bairro e com a história singular que marcou este último nas passadas décadas.

Como nos diz a organização:

A escolha do bairro da Relvinha [...] para palco da realização foi uma escolha que envolveu vários factores: o facto de manter uma associação de moradores constituída, um passado de auto-construção, activismo e cooperativismo popular, numa zona industrial em processo de desagregação, no centro de um conjunto de bairros residenciais de características diversificadas e relações complexas. Estes factores, imensamente sugestivos, deviam funcionar como catalisadores da reacção artística. (Pro Urbe, 2003: 2)

Quando Estiver Lá em Cima Estará Completamente à Vontade! constituiu-se como uma versão radicalizada do tipo de actuações especificamente situadas, uma vez que o Bairro da Relvinha se converteu num amplo espaço cénico - impossível de reproduzir noutro lugar - do qual actores e espectadores se apropriavam caminhando por vários dos seus pontos de passagem e locais de referência. ${ }^{12} \mathrm{~A}$ acção decorria em diversos sítios e era preciso ir a pé para cada um deles. Deste modo, actores e público iam atravessando, conhecendo ou reconhecendo lugares de circulação e vida daquela zona. As cenas desenrolavam-se em diversos contextos convocando a paragem

\footnotetext{
12 A entrada neste espectáculo - tal como a entrada num qualquer bairro, aliás - era livre, não sendo, portanto, necessário comprar qualquer tipo de bilhete.
} 
dos espectadores: escadas públicas, campo de futebol, recinto de bailes ao ar livre, ruas e ruelas, hortas, pátios e rotundas. Assistíamos, pois, à participação de uma cenografia singular constituída pelos próprios edifícios, lugares de trânsito ou de referência desta espacialidade urbana.

A transfiguração dos locais ou a sua revisitação histórico-artística fez-se sentir em momentos muito especiais. Cito um exemplo significativo. Uma das cenas do espectáculo decorria no recinto rectangular de cimento ao ar livre onde é costume a comunidade reunir-se para os bailes. Pois bem, aí chegados, os espectadores eram confrontados com um chão, já não de cimento, mas sim, coberto de relva e, por cima das suas cabeças, podiam ver penduradas ao contrário muitas flores. Neste espaço concreto realizou-se uma espécie de festa/baile/desfile com diversas personagens que convidavam os espectadores a entrar para o recinto e que com eles falavam e propunham diversas acções.

O texto e cenas desta actuação teatral aliavam-se a uma ideia de pensar a urbanidade, na medida em que foram inspirados significativamente pelas histórias dos habitantes deste bairro, pela memória do movimento de auto-construção popular após o 25 de Abril de 1974 e pelo quotidiano desta zona de Coimbra. Sendo assim, não admira que, em diversas partes do espectáculo, os moradores da Relvinha estivessem na posse de muitos mais elementos para entender o que se passava do que o resto do público. Por exemplo, num dos momentos da actuação, os espectadores, situados numa das ruas do Bairro, assistiram à sequência de uma série de imagens relativas ao período a seguir à Revolução em que a Associação de Moradores deitou mãos à obra para construir casas na Relvinha. Estas imagens eram projectadas na parede de uma habitação do Bairro e tinham, portanto, uma considerável dimensão. Durante esta cena, os actores colocaram-se perto desta parede e pronunciaram uma série de palavras de ordem e de acção que remetiam para o dinamismo, energia e espírito colectivo vividos nesses tempos. Um dos aspectos curiosos deste momento do espectáculo reside no facto de se ter concretizado junto da Oficina do Bairro da Relvinha que irá ser recuperada e reabilitada na primeira fase de edificação da futura sede social e centro cultural da Cooperativa Semearrelvinhas. ${ }^{13}$ Ou seja, a ideia de construção foi reafirmada.

${ }^{13} \mathrm{O}$ estudo prévio para o projecto desse equipamento resultou do processo inerente ao relvinha.cbr_x. Foi apresentado pelo arquitecto João Mendes Ribeiro numa sessão pública realizada no dia 19 de Dezembro de 2003 precisamente na mencionada Oficina do Bairro da Relvinha. Os planos arquitectónicos para esta sede resultaram do diálogo com os moradores do bairro, facto registado, aliás, no documentário exibido igualmente no encontro atrás referido e que mostrava momentos importantes do processo de concretização do projecto da Pro Urbe do qual resultou a criação teatral aqui analisada. 
Tudo isto não significa, porém, que a dramaturgia e acções deste espectáculo apenas tivessem como referente a história e vida do bairro; em diversos momentos, as questões em causa eram de carácter geral ou universal, levando a interrogações metafísicas ou a uma denúncia de males e vícios das sociedades contemporâneas. Esta diversidade estava, contudo, marcada temporal e espacialmente.

A primeira parte do espectáculo reflecte histórias do próprio bairro, episódios fragmentários do quotidiano, das vidas das pessoas. As cenas sucedem-se nas escadas $[\ldots]$, na escola $[\ldots]$, no centro do bairro $[\ldots]$, nas varandas das habitações $[\ldots]$. Depois o espectáculo segue para as ruas limítrofes, onde "as cenas têm outro carácter, em que se pensa já não tanto o bairro, mas mais o mundo visto da Relvinha”, adianta Carlos Pessoa. (Loureiro, 2003: 16)

O espectáculo Quando Estiver Lá em Cima Estará Completamente à Vontade! remete-nos ainda para outro dos parâmetros que deve servir de base a uma análise do teatro realizado em espaços não teatrais. Com efeito, ao interrogarmo-nos sobre os modos através dos quais estes últimos são usados e apropriados, precisamos de ter em conta, como se sabe, de que maneira a experiência artística coloca actores e espectadores. No caso do teatro nos teatros, estamos habitualmente perante uma realidade estacionária, ou seja, assistimos a uma peça sentados e presos à cadeira que nos coube na plateia ou no balcão. Os actores, por seu lado, ficam presos ao espaço cénico enquadrado dentro da sala do equipamento cultural em causa. Assim, é preciso indagar sobre as possibilidades que os espaços não convencionais oferecem para o passeio, viagem, deambulação e trânsito.

Ora, o espectáculo realizado na zona da Relvinha contrasta de forma muito vincada com a experiência estacionária de ver teatro nos teatros. Espectadores e actores realizavam um extenso percurso - um quilómetro e meio (Loureiro, 2003: 16) - envolvendo-se pelo bairro adentro e visitando também os seus lugares de fronteira e saída. Durante mais de duas horas e meia, o espectáculo exigia a cumplicidade que existe entre aqueles que partilham um mesmo itinerário. A ideia de viagem era reforçada, desde logo, se pensarmos no seu ponto de partida e no seu ponto de chegada: como nos diz Carlos J. Pessoa, "começamos por baixo do viaduto ${ }^{14}$ e acabamos por cima do viaduto, na expectativa de passar a auto-estrada" (apud Loureiro, 2003: 16).

\footnotetext{
${ }^{14}$ Trata-se, mais concretamente, do viaduto do IC2, na Estrada de Eiras, à entrada do Bairro da Relvinha.
} 


\section{Nota final: criadores fora dos teatros}

Para terminar este texto e com base na abordagem dos três casos analisados, gostaria de indicar, ainda que de forma breve, algumas pistas que permitam o desenvolvimento do estudo sociológico das criações teatrais que são apresentadas em locais não concebidos para acolher actividades artísticas.

Em primeiro lugar, é preciso perguntar, a respeito de cada actuação teatral que tem lugar num espaço não convencional, se ela foi concebida de raiz para esse mesmo espaço. Em caso afirmativo, estamos perante um processo de criação inspirado, desde o seu início, por uma ideia de sair da esfera do teatro nos teatros. Não se trata, portanto, de fazer uma versão modificada ou com ajustamentos de uma peça apresentada numa sala de espectáculos, mas sim de pensar desde a origem (originalmente) discursos e acções em função de uma determinada espacialidade.

Esta questão ganha sentido, na medida em que a opção por fazer teatro fora dos teatros pode ser ditada por razões instrumentais ou de resposta a condições limitadas. Se é verdade que a escolha de espaços não convencionais foi ditada, em parte, "de modo a se escapar da tirania da grandeza arquitectónica e das suas implicações estéticas e ideológicas" (Elam apud Bennett, 2003: 127), ela derivou igualmente, em parte, do facto de tais lugares serem os únicos "disponíveis para os grupos de teatro não tradicionais" (Bennett, 2003: 127). Este comentário ganha um significado acrescido, se considerarmos a diferença apontada por Vera Borges entre espaços alternativos e espaços disponiveis (Borges, 2002: 97 e 98). Esta autora, ao analisar sociologicamente o teatro profissional em Portugal, constata que actualmente

a propensão para certos grupos contrariarem os espaços reconhecidos para a apresentação dos trabalhos artísticos é um dado adquirido que se acentua, por razões que podem não estar directamente relacionadas com as preferências estéticas ou as provocações das vanguardas. (ibid.)

Isto significa que a decisão relativa aos lugares onde se trabalhará e onde decorrerá um determinado evento teatral pode derivar de condicionalismos e constrangimentos que levam determinados artistas e grupos sobretudo a tentar tirar partido dos espaços disponíveis para o efeito (ibid.: 98)..$^{15}$

${ }_{15}$ No seu texto sobre intervenções artísticas e desdiferenciação do espaço público, Joana Sousa Ribeiro não deixa de constatar também que alguns dos agentes culturais por si estudados "salientam a necessidade de terem um espaço próprio que lhes permita não só programar melhor as suas actividades, por exemplo, os ensaios, como também criar laços com a comunidade" (Ribeiro, 2002: 12). Logo de seguida, acrescenta que "em agentes culturais que sempre se debateram com esse problema, a falta de espaços culturais é um dos aspectos mais realçados, quando avaliam as dificuldades do exercício da actividade cultural em Portugal" (ibid.). 
Interessa igualmente saber de que modo se procede à selecção do espaço não convencional onde decorrerá uma actuação teatral. Dada a heterogeneidade deste tipo de contextos, é importante conhecer a saliência e a centralidade das motivações e dos argumentos que levam a escolher, por exemplo, a rua e não a igreja, a prisão e não o bairro, como locais de apresentação de um espectáculo. Com efeito, mesmo espaços não convencionais com importantes afinidades podem conduzir a efeitos bem diferenciados no modo como se apresenta uma peça ou na maneira como esta última pode estabelecer a relação entre actores e espectadores.

$\mathrm{Na}$ tentativa de conhecer e de analisar o processo reflexivo subjacente às criações teatrais realizadas fora dos teatros, não basta, porém, saber como se escolheu um determinado tipo de espaço não convencional, parque ou rua, por exemplo. É preciso igualmente compreender de que maneira se avaliou e se ponderou a opção pelo sítio concreto a que diz respeito esse tipo de espacialidade. De facto, quando se decide fazer uma determinada actuação na igreja, no parque ou na rua, vai igualmente fazer-se uma escolha relativamente a uma igreja em concreto, a um parque em concreto ou a uma rua em concreto. Independentemente da maior ou menor maturação a que são sujeitas, tais opções terão sempre efeitos relevantes, dado que cada sítio em particular se diferencia dos restantes do mesmo género. Um espectáculo pode funcionar melhor numa rua do que noutra, por exemplo. De facto, a rua - tal como os outros tipos de espaços não convencionais para a apresentação de actuações artísticas - tem de ser vista no plural.

\section{Referências Bibliográficas}

Amaral, Marina et al. (2001), "Augusto Boal exilado”, Caros Amigos, 48, 28-33 [entrevista concedida por Augusto Boal].

ar (2003), Goblin Market LEL. (programa da criação artística produzida pelo grupo arexploratório das artes).

Bennett, Susan (2003), Theatre Audiences: a Theory of Production and Reception. Londres, Nova Iorque: Routledge.

Boal, Augusto (2000), Theater of the Oppressed. Londres: Pluto Press.

Borges, Vera (2002), “Artistas em rede ou artistas sem rede? Reflexões sobre o teatro em Portugal”, Sociologia, Problemas e Práticas, 40, 87-106.

Coimbra 2003 (2003a), "Estabelecimento Prisional de Coimbra associa-se à Capital Nacional da Cultura" (texto de 18 de Julho). Disponível em: http://www. coimbra 2003.pt/ie/noticias/imprimir.asp?nid=385 (acedido em 30 de Dezembro de 2003).

Coimbra 2003 (2003b), "Só entra se vier às fatias" (volante com informação sobre o espectáculo). 
Coimbra 2003 (2003c), “«Só Entra Se Vier Às Fatias»: Para dizer que «Aqui... vivem HOMENS!»” (texto de 18 de Dezembro). Disponível em: http://www. coimbra 2003.pt/ie/noticias/imprimir.asp?nid=522 (acedido em 30 de Dezembro de 2003).

Goffman, Erving (1975), Asiles. Paris: Les Éditions de Minuit.

Heritage, Paul (2001), “Teatro nas Prisões”, Metaxis - A Revista do Teatro do Oprimido, 1,32 e 33 .

Jardim Botânico de Coimbra (s/d-a), “Mensagem”. Disponível em: http://www.uc.pt/ botanica/mensagem.htm (acedido em 22 de Novembro de 2003).

Jardim Botânico de Coimbra (s/d-b), "História e vocação do Jardim Botânico de Coimbra”. Disponível em: http://www.uc.pt/botanica/Jardbot.htm (acedido em 22 de Novembro de 2003).

Loureiro, Dora (2003), “Do bairro se fez palco”, As Beiras (edição de 2 de Setembro), 16.

Morais, Nelson (2003), "Um barco na prisão", Diário de Coimbra (edição de 17 de Dezembro), 24.

Pro Urbe (2003), "Algumas linhas serenas sobre uma intervenção participada”, in programa da criação artística Quando Estiver Lá em Cima Estará Completamente à Vontade!.

Ribeiro, Joana Sousa (2002), "A cultura e a (des)diferenciação do espaço público", in AA.VV., Sociedade portuguesa: passados recentes, futuros próximos - Actas do IV Congresso Português de Sociologia. Lisboa: Associação Portuguesa de Sociologia (em CDROM).

Schechner, Richard (1998), "The Street is the Stage”, in Jan Cohen-Cruz (org.), Radical Street Performance. Londres, Nova Iorque: Routledge, 196-207.

Serôdio, Maria Helena (1998), “Theatre as a Social System: Portugal”. Disponível em: http://www.ip.pt/centro-estudos-teatro/publications/artigo1.html (acedido em 10 de Novembro de 2000).

Serôdio, Maria Helena (1999), "Growing Up and Gaining Visibility (1996-1999)”. Disponível em: http://www.fl.ul.pt/artigo5.htm (acedido em 23 de Outubro de 2000).

Vieira, Álvaro (2003), “Nesta peça «só entra se vier às fatias»”, Público (edição de 17 de Dezembro), 37.

Visões Úteis (1999), Visões Úteis, 5 Anos. (edição comemorativa dos cinco anos de existência do grupo). 